\title{
KAPASITAS DAERAH BANJARNEGARA DALAM PENANGGULANGAN BENCANA ALAM TANAH LONGSOR
}

\author{
Amni Zarkasyi Rahman \\ Program Studi S1 Administrasi Publik FISIP Universitas Diponegoro \\ Jl. Prof. H. Soedarto, Tembalang, Kota Semarang, Jawa Tengah 50139 \\ e-mail:amni.zr@gmail.com
}

\begin{abstract}
Capacity assessment is a parameter in determining the success of disaster risk reduction. The reference for the assessment of capacity in Indonesia is the Hyogo Framework for Action (HFA) agreed by 160 countries in disaster risk reduction efforts. The implementation of the HFA in Indonesia is ACT 24/2007 about the disaster relief. The capacity assessment was conducted to find out how disaster mitigation efforts in Banjarnegara by looking at disaster mitigation priorities. The purpose of this study was to describe the score capacity in disaster management and disaster risk reduction efforts.

The results of this research is the capacity score disaster relief in the region reached $70.46 \%$ from 88 indicators so that fall into the category B. It means capacity in Banjarnegara district into disaster management can already be said either. From these results, the main concern is the basic risk factors reduce the efforts through the establishment of "Desa Tangguh Bencana".
\end{abstract}

Keywords: Capacity, Assessment, Disaster

\section{PENDAHULUAN}

Kapasitas daerah dalam penyelenggaraan penanggulangan bencana merupakan parameter penting untuk menentukan keberhasilan untuk pengurangan risiko bencana. Kapasitas daerah dalam penanggulangan bencana harus mengacu kepada Sistem Penanggulangan Bencana Nasional yang dicantumkan dalam Undang-undang Nomor 24 Tahun 2007 tentang Penanggulangan Bencana serta turunan aturannya (Indonesia, 2007). Kapasitas daerah harus melihat kepada tatanan pada skala internasional (Indonesia, 2008). Komprehensivitas dasar acuan untuk kapasitas daerah diharapkan dapat memberikan arah kebijakan pembangunan kapasitas daerah untuk penyelenggaraan penanggulangan bencana (UNDP, 2009).

Pada skala internasional, Kerangka Aksi Hyogo (selanjutnya disebut KAH) dapat dijadikan sebagai salah satu acuan dasar pembangunan kapasitas. KAH merupakan kesepakatan lebih dari 160 negara untuk mengarusutamakan pengurangan risiko bencana dalam pembangunan. Indonesia sebagai salah satu negara yang menyepakati KAH, meratifikasi KAH dalam Sistem Penanggulangan Bencana Nasional. Wujud ratifikasi KAH antara lain Undang-undang Nomor 24 Tahun 2007 tentang Penanggulangan Bencana, Rencana Nasional Penanggulangan Bencana, Rencana Aksi Nasional Pengurangan Risiko Bencana dan lainnya. Setiap tahunnya, Indonesia melaporkan pencapaian KAH ke salah satu sekretariat PBB yang bernama UN-ISDR (United Nations International Strategic for Disaster Reduction) (BNPB, 2012b).

Pengalaman memperlihatkan bahwa kejadian-kejadian bencana alam selama ini telah banyak menimbulkan kerugian dan penderitaan yang cukup berat sebagai akibat dari perpaduan bahaya alam dan kompleksitas permasalahan lainnya. Sebagai contoh adalah Bencana Tanah Longsor di Dusun Jemblung, Kecamatan Karangkobar Kabupaten Banjarnegara yang menimbulkan banyak korban jiwa.

Banjarnegara adalah Kabupaten yang memiliki kawasan pegunungan dengan resiko tanah longsor cukup tinggi (lebih dari $70 \%$ wilayah rawan longsor). Penilaian kapasitas daerah Kabupaten Banjarnegara 
menggunakan indikator KAH yang diadaptasikan dengan Undang-undang Nomor 24 Tahun 2007 tentang Penanggulangan Bencana beserta peraturan turunannya menjadi penting untuk dilakukan sehingga terdapat kesiapan daerah dalam penanggulangan bencana dikemudian hari.

Oleh sebab itu, diperlukan upaya-upaya yang komprehensif untuk menilai kapasitas daerah dalam upaya penanggulangan bencana tanah longsor yang terjadi di Kabupaten Banjarnegara. Tujuan dari penelitian ini adalah untuk mendiskripsikan kapasitas Kabupaten Banjarnegara dalam penanggulangan bencana tanah longsor dan mengetahui upaya peningkatan kapasitas Kabupaten Banjarnegara dalam penanggulangan bencana tanah longsor.

\section{METODE PENELITIAN}

Penelitian ini merupakan jenis penelitian deskriptif, dengan menggunakan pendekatan kuantitatif dan kualitatif dalam menjabarkan Kapasitas Daerah dalam penanggulangan bencana tanah longsor. Penelitian ini akan menggunakan teknik purposive sampling yaitu peneliti telah menentukan tempat atau informan yang dituju, dalam penelitian ini adalah Badan Perencanaan Pembangunan Daerah Kabupaten Banjarnegara (BAPPEDA Kabupaten Banjarnegara); Badan Penanggulangan Bencana Daerah Kabupaten Banjarnegara (BPBD Kabupaten Banjarnegara); Dinas Sosial, Tenaga Kerja, dan Transmigrasi Kabupaten Banjarnegara; Dinas Kesehatan Kabupaten Banjarnegara, dan tokoh-tokoh masyarakat di sekitar lokasi rawan/ terdampak bencana longsor di Kabupaten Banjarnegara.

Aspek yang akan diamati dalam penelitian ini adalah kapasitas daerah dalam upaya penanggulangan bencana alam tanah longsor, dengan melihat prioritas program pengurangan resiko bencana serta upaya mitigasi bencana yang telah dilakukan oleh BPBD Kabupaten Banjarnegara.

\section{HASIL PENELITIAN DAN PEMBAHASAN}

\section{Kapasitas Daerah dalam Penanggulangan Bencana}

Hasil penilaian kapasitas daerah dalam penyelenggaraan penanggulangan bencana dilakukan dengan metode kuantitatif, dengan memperhatikan hasil hitung secara rata-rata prosentase masing-masing indikator. Nilai kemampuan (dalam persentase) dihitung dengan membandingkan score yang didapat dengan maximum score. Klasifikasi nilai dan kategori kemampuan adalah sebagai berikut :

Tabel 1 Klarifikasi Nilai Kapasitas Daerah

\begin{tabular}{|c|c|l|}
\hline NILAI (\%) & KATEGORI & \multicolumn{1}{c|}{ KETERANGAN } \\
\hline Diatas $80 \%$ & $\mathrm{~A}$ & $\begin{array}{l}\text { kapasitas daerah dalam penyelenggaran penanggulangan } \\
\text { bencana sangat baik }\end{array}$ \\
\hline $70 \%$ hingga $80 \%$ & $\mathrm{~B}$ & $\begin{array}{l}\text { kapasitas daerah dalam penyelenggaraan penanggulangan } \\
\text { bencana baik }\end{array}$ \\
\hline $60 \%$ hingga $70 \%$ & $\mathrm{C}$ & $\begin{array}{l}\text { kapasitas daerah dalam penyelenggaraan penanggulangan } \\
\text { bencana cukup memadai }\end{array}$ \\
\hline $50 \%$ hingga $60 \%$ & $\mathrm{D}$ & $\begin{array}{l}\text { kapasitas daerah dalam penyelenggaraan penanggulangan } \\
\text { bencana kurang, memerlukan peningkatan kemampuan }\end{array}$ \\
\hline Dibawah $50 \%$ & $\mathrm{E}$ & $\begin{array}{l}\text { kapasitas daerah dalam penyelenggaran penanggulangan } \\
\text { bencana sangat kurang, memerlukan peningkatan kemam- } \\
\text { puan secara intensif }\end{array}$ \\
\hline
\end{tabular}

Sumber : Dikembangkan dari Widjono Ngoedijo dan USAID, 1999 
Lebih lanjut, penilaian kapasitas daerah dalam penanggulangan bencana dilakukan dengan melihat 5 (lima) prioritas program pengurangan rsiko bencana. Adapun prioritas ini diadopsi dalam Kerangka Aksi Hangyo (KAH) dengan masing-masing memiliki indikator pencapaian.

Prioritas pertama adalah memastikan bahwa pengurangan risiko bencana menjadi sebuah prioritas nasional dan lokal dengan dasar kelembagaan yang kuat untuk pelaksanaannya. Dalam pelaksanan prioritas 1 ini, terdapat 4 indikator dengan total 16 pertanyaan. indikator ke-1 adalah kerangka hukum yang lengkap dalam aspek penangggulangan bencana. indikator ke-2 adalah tersedianya sumberdaya yang dialokasikan khusus untuk kegiatan pengurangan risiko bencana di semua tingkat pemerintahan. indikator ke-3 adalah terjalinnya partisipasi dan desentralisasi komunitas melalui pembagian kewenangan dan sumber daya pada tingkat lokal. indikator ke-4 adalah berfungsinya forum/jaringan daerah khusus untuk pengurangan risiko bencana.

Hasil persentase yang dihasilkan dari prioritas ini adalah 68,75\%, sehingga masuk dalam kategori C, yang berarti kapasitas daerah dalam Pengurangan Risiko Bencana menjadi sebuah Prioritas Nasional dan Lokal dengan Dasar Kelembagaan yang Kuat untuk Pelaksanaannya cukup memadai. Perolehan presentasi ini dipengaruhi oleh belum terpenuhinya sumber daya yang terkait dengan PRB pada BPBD (dana, sarana, prasarana, personil) baik dalam hal kualitas maupun kuantitasnya. Selain itu, belum terdapat monitoring efektif oleh masyarakat dalam pengelolaan dana penanggulangan bencana, disamping belum adanya forum yang berfungsi untuk mempercepat upaya pengurangan risiko bencana di daerah yang terdiri dari aktor-aktor dari beda kelompok seperti pemerintah, LSM, PMI, Akademisi, Media, dan Ulama.

Prioritas kedua adalah tersedianya kajian risiko bencana daerah berdasarkan data bahaya dan kerentanan untuk meliputi risiko untuk sektor-sektor utama daerah. Dalam pelaksanan prioritas 2 ini, terdapat 4 indikator dengan total 16 pertanyaan. indikator ke-1 adalah tersedianya kajian risiko bencana daerah berdasarkan data bahaya dan kerentanan untuk meliputi risiko untuk sektor-sektor utama daerah. indikator ke-2 adalah tersedianya sistem-sistem yang siap untuk memantau, mengarsip dan menyebarluaskan data potensi bencana dan kerentanan-kerentanan utama. indikator ke-3 adalah tersedianya sistem peringatan dini yang siap beroperasi untuk skala besar dengan jangkauan yang luas ke seluruh lapisan masyarakat. indikator ke-4 adalah penilaian risiko daerah mempertimbangkan risiko-risiko lintas batas guna menggalang kerjasama antar daerah untuk pengurangan risiko.

Hasil persentase yang dihasilkan dari prioritas ini adalah 93,75\%, sehingga masuk dalam kategori A, yang berarti kapasitas daerah dalam penyediaan Kajian Risiko Bencana Daerah berdasarkan data bahaya dan kerentanan untuk meliputi risiko untuk sektor-sektor utama daerah adalah sangat baik. Hasil ini dapat dilihat dari ketersediaan dokumen kajian resiko bencana Kabupaten Banjarnegara yang dilengkapi dengan peta resiko bencana dan diperbaharui secara periodik. Selain itu, terdapat pula sistem peringatan dini untuk setiap bencana yang sering terjadi. Alat peringatan dini saat ini telah terpasang alat deteksi peringatan dini bahaya longsor di berbagai tempat. Akan tetapi, terdapat sebagian masyarakat yang enggan untuk menerima pemasangan alat deteksi dini sebagai bagian dari sistem peringatan dini longsor atau Landslide Early Warning System (LEWS) Kabupaten Banjarengara (Rahman, 2015).

Selanjutnya, prioritas ketiga adalah terwujudnya penggunaan pengetahuan, inovasi dan pendidikan untuk membangun kapasitas dan budaya aman dari bencana di semua tingkat. Dalam pelaksanan prioritas 3 ini, terdapat 4 indikator dengan total 16 pertanyaan. indikator ke-1 adalah tersedianya informasi yang relevan mengenai bencana dan dapat diakses di semua tingkat oleh seluruh pemangku kepentingan (melalui jejaring, 
pengembangan sistem untuk berbagi informasi, dst). indikator ke-2 adalah kurikulum sekolah, materi pendidikan dan pelatihan yang relevan mencakup konsep-konsep dan praktik-praktik mengenai pengurangan risiko bencana dan pemulihan. indikator ke-3 adalah tersedianya metode riset untuk kajian risiko multi bencana serta analisis manfaat-biaya (cost benefit analysist) yang selalu dikembangkan berdasarkan kualitas hasil riset. indikator ke-4 adalah diterapkannya strategi untuk membangun kesadaran seluruh komunitas dalam melaksanakan praktik budaya tahan bencana yang mampu menjangkau masyarakat secara luas baik di perkotaan maupun pedesaan.

Hasil persentase yang dihasilkan dari prioritas ini adalah 56,25\%, sehingga masuk dalam kategori D, yang berarti kapasitas daerah dalam penggunaan pengetahuan, inovasi dan pendidikan untuk membangun kapasitas dan budaya aman dari bencana di semua tingkat adalah kurang sehingga memerlukan peningkatan kemampuan (BPBD). Hasil ini dapat dilihat dari tidak adanya pelajaran tentang pengurangan risiko bencana beberapa sekolah di wilayah rawan bencana. Selain itu, belum digunakannya hasil riset untuk memantau ancaman bencana dan menurunkan kerentanan daerah terhadap risiko multi bencana. Hal ini menjadi penting melihat efek domino dari bencana tanah longsor yang kerap terjadi. Hal penting yang perlu mendapatkan perhatian dan peningkatan adalah metode untuk mengukur keberhasilan strategi dan perencanaan publikasi yang diterapkan pada wilayah rawan bencana di Kabupaten Banjarnegara dalam meningkatkan praktik budaya pengurangan risiko bencana (Mubekti, 2011).

Prioritas keempat adalah mengurangi faktor-faktor risiko dasar. Dalam pelaksanan prioritas 4 ini, terdapat 6 indikator dengan total 24 pertanyaan. indikator ke-1 adalah pengurangan risiko bencana merupakan salah satu tujuan dari kebijakan-kebijakan dan rencana-rencana yang berhubungan dengan lingkungan hidup, termasuk untuk pengelolaan sumber daya alam, tata guna lahan dan adaptasi terhadap perubahan iklim. Indikator ke-2 adalah rencana-rencana dan kebijakan-kebijakan pembangunan sosial dilaksanakan untuk mengurangi kerentanan penduduk yang paling berisiko terkena dampak bahaya. Indikator ke-3 adalah rencanarencana dan kebijakan-kebijakan sektoral di bidang ekonomi dan produksi telah dilaksanakan untuk mengurangi kerentanan kegiatan-kegiatan ekonomi. Indikator ke-4 adalah perencanaan dan pengelolaan pemukiman manusia memuat unsur-unsur pengurangan risiko bencana termasuk pemberlakuan syarat dan izin mendirikan bangunan. Indikator ke-5 adalah langkah-langkah pengurangan risiko bencana dipadukan ke dalam proses-proses rehabilitasi dan pemulihan pascabencana. Indikator ke-6 adalah siap sedianya prosedur-prosedur untuk menilai dampak-dampak risiko bencana atau proyek- proyek pembangunan besar, terutama infrastruktur.

Hasil persentase yang dihasilkan dari prioritas ini adalah 58,33\%, sehingga masuk dalam kategori D, yang berarti kapasitas daerah dalam mengurangi faktor-faktor risiko dasar adalah kurang sehingga memerlukan peningkatan kemampuan (pengurangan faktor-faktor resiko bencana). Hasil ini dapat dilihat dari tidak adanya aksi-aksi sosial (seperti program kapasitas jaringan pangan, kesehatan, membangun perekonomian untuk menekan terbentuknya kelompok masyarakat miskin, asuransi infrastruktur, asuransi asset penduduk lainnya) untuk mengurangi kerentanan penduduk dari berbagai pemangku kepentingan yang telah ditentukan dalam kebijakan-kebijakan pembangunan sosial. Hal ini juga diperkuat dengan tidak adanya kegiatan-kegiatan yang terukur dan terarah berdasarkan rencana yang matang untuk meningkatkan kapasitas komunitas dibidang ekonomi dan produksi yang ditujukan untuk pengurangan risiko bencana. Selain itu, kontrol daerah untuk mengurangi resiko bencana juga terhambat oleh tidak adanya tindakan hukum terhadap pemukiman penduduk yang tidak direncanakan dan dikelola berdasarkan rencana tata guna lahan, IMB dan perluasannya, serta tidak 
adanya prosedur analisis resiko bencana yang dapat menilai dampak-dampak risiko bencana untuk proyekproyek lain seperti pengentasan kemiskinan, perumahan, air dan energi selain infrastruktur. Hal ini dapat dilakukan dengan turut memperhatikan Peta Rawan Bencana yang termuat dalam dokumen RTRW Kabupaten Banjarnegara Tahun 2011-2031.

Gambar 1 Peta Rawan Gerakan Tanah Kabupaten Banjarnegara

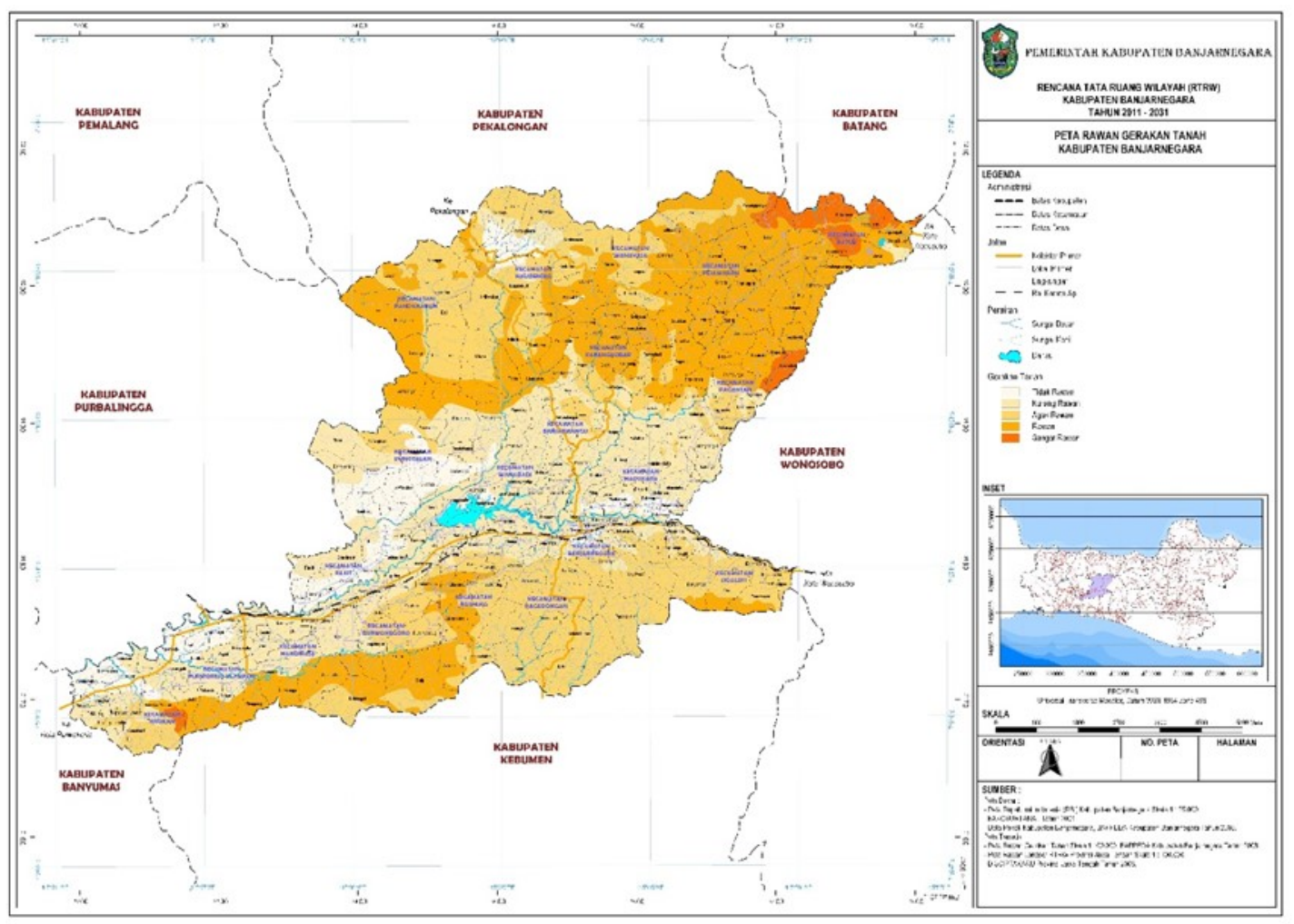

Sumber : RTRW Kabupaten Banjarnegara Tahun 2011-2031

Sedangkan prioritas terakhir adalah memperkuat kesiapsiagaan terhadap bencana demi respon yang efektif di semua tingkat. Dalam pelaksanan prioritas 4 ini, terdapat 4 indikator dengan total 16 pertanyaan. indikator ke-1 adalah tersedianya kebijakan, kapasitas teknis kelembagaan serta mekanisme penanganan darurat bencana yang kuat dengan perspektif pengurangan risiko bencana dalam pelaksanaannya. Indikator ke2 adalah tersedianya rencana kontinjensi bencana yang berpotensi terjadi yang siap di semua jenjang pemerintahan, latihan reguler diadakan untuk menguji dan mengembangkan program- program tanggap darurat bencana. Indikator ke-3 adalah tersedianya cadangan finansial dan logistik serta mekanisme antisipasi yang siap untuk mendukung upaya penanganan darurat yang efektif dan pemulihan pasca bencana. Indikator ke-4 adalah tersedianya prosedur yang relevan untuk melakukan tinjauan pasca bencana terhadap pertukaran informasi yang relevan selama masa tanggap darurat.

Hasil persentase yang dihasilkan dari prioritas ini adalah 81,25\%, sehingga masuk dalam kategori A, yang berarti kapasitas daerah dalam memperkuat kesiapsiagaan terhadap bencana demi respon yang efektif di 
semua tingkat adalah sangat baik. Hasil ini dapat dilihat adanya sistem komando tanggap darurat yang terintegrasi BPBD dan Pemkab Banjarnegara dalam segala penanganan bencana alam. Hal ini turut diperkuat dengan adanya mekanisme untuk penggalangan bantuan dari pihak lain ketika terjadi bencana, seperti ketika terjadi bencana longsor Karangkobar yang terjadi pada 26 Desember 2016.

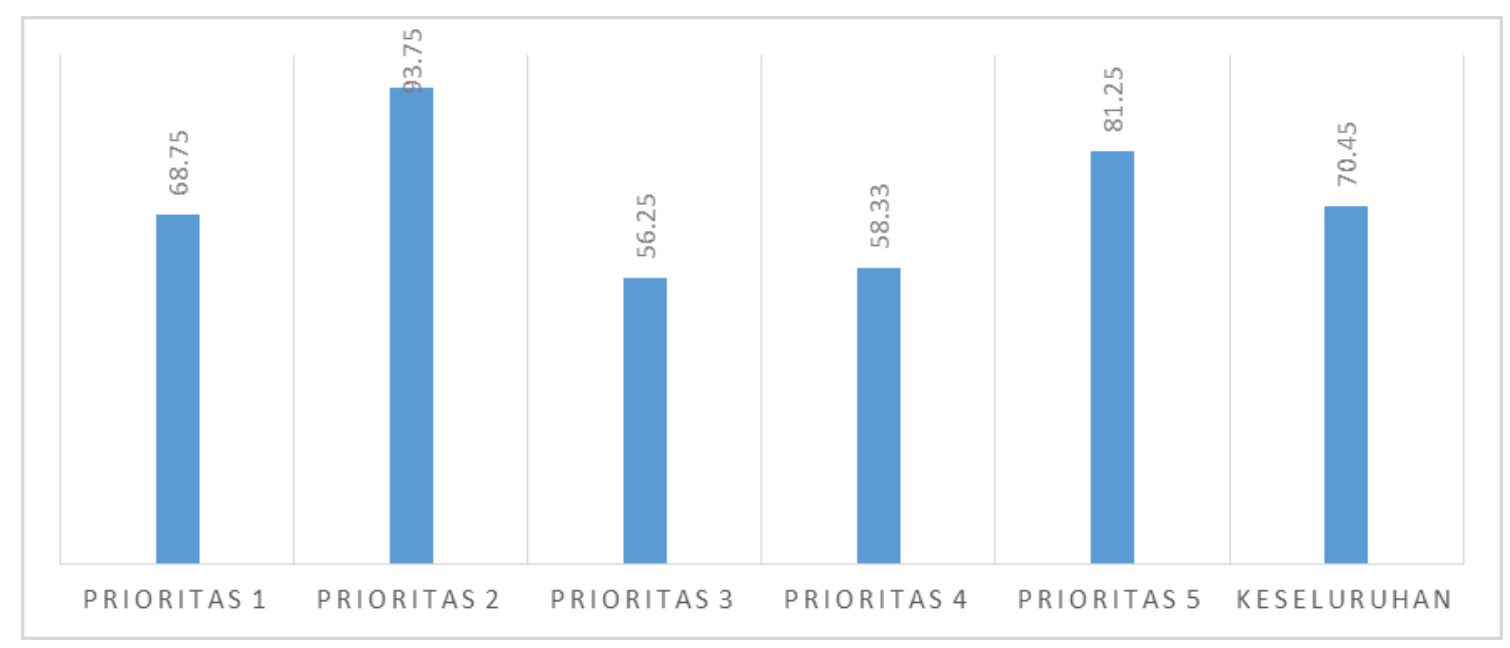

Gambar 2 Grafik Hasil Persentase Penilaian masing-masing Prioritas

Sumber : Data diolah, 2016

Secara keseluruhan, hasil penilaian kapasitas Kabupaten Banjarnegara dalam penyelenggaraan penanggulangan bencana mencapai $70,45 \%$. Hasil persentase ini menjadikan kapasitas daerah Kabupaten Banjarnegara masuk dalam kategori $\mathrm{B}$, yang berarti kapasitas daerah dalam penyelenggaraan penanggulangan bencana baik.

Upaya Peningkatan Kapasitas Daerah dalam Penangglangan Bencana

Upaya peningkatan kapasitas daerah dalam penanggulangan bencana lebih diarahkan pada upaya pengurangan risiko bencana. Menurut Yanuarko, (Profil PUM, Majalah Direktorat Jenderal Pemerintahan Umum, 2007), upaya pengurangan bencana harus ditingkatkan. Konferensi pengurangan risiko bencana sedunia (World Conference for Disaster Reduction/WCDR) di Kobe, Jepang, pada tanggal 18-25 Januari 2005 dan konferensi asia (Asian Conference fot Disaster Reduction/ACDR) di Beijing, China, pada tanggal 27-29 September 2005 tentang pengurangan risiko bencana adalah dasar tekad dan program kerja masyarakat sedunia dalam mengurangi risiko bencana, yang melahirkan Hyogo Framework for Action/HFA (Kerangka Kerja Aksi Hyogo 2005-2015) yaitu membangun ketahanan bangsa dan komunitas terhadap bencana (Building the Resilience of nation and communities to disasters) (Wuryanti, 2006).

Ketahanan bangsa dalam bencana merupakan kekuatan, kemampuan, daya tahan, dan keuletan yang menjadi tujuan suatu bangsa untuk menghadapi tantangan, ancaman, hambatan, dan gangguan dari bencana alam yang terjadi. Hal ini dapat dilakukan dengan pembangunan manusia melalui pemberdayaan sehingga menjadi masyarakat tangguh bencana. Masyarakat yang tangguh bencana ialah masyarakat yang mampu mengantisipasi dan meminimalisir kekuatan yang merusak, melalui adaptasi. Mereka juga mampu mengelola dan menjaga struktur dan fungsi dasar tertentu ketika terjadi bencana. Apabila terkena dampak bencana, 
mereka akan dengan cepat bisa membangun kehidupannya menjadi normal kembali atau paling tidak dapat dengan cepat memulihkan diri secara mandiri.

Desa Tangguh merupakan program nasional dari BNPB (Perka BNPB 01/2012) dalam rangka mewujudkan Indonesia Tangguh. Program ini merupakan wujud tanggungjawab pemerintah terhadap masyarakatnya dalam hal penanggulangan bencana. Karena masyarakat yang merupakan penerima dampak langsung dari bencana, dan sekaligus sebagai pelaku pertama dan langsung yang akan merespon bencana disekitarnya. Maka masyarakat perlu dibekali dalam konteks pemberdayaan agar menjadi Tangguh, bukan hanya siap menghadapi bencana tapi menjadi TANGGUH.

Masyarakat tangguh adalah mampu mengantisipasi dan meminimalisasi kekuatan yang merusak (ancaman bencana), dengan cara melakukan adaptasi; mampu mengelola dan menjaga stuktur dan fungsi dasar tertentu ketika terjadi bencana; jika terkena dampak bencana, mereka akan dengan cepat bisa membangun kehidupannya menjadi normal kembali (BNPB, 2012a). Program desa tangguh tanggap bencana, dikhususkan untuk desa yang berpotensi mengalami bencana longsor. Tujuan pembentukan desa tangguh tanggap bencana, untuk menyiapkan masyarakat yang lebih siap menghadapi bencana.

Desa tangguh bencana di Kabupaten Banjarnegara saat ini paling tinggi pada level madya, diantaranya Desa Kalitraga, Desa Kertosari, Desa Karangtengah, Desa Tiaga, dan Desa Sijeruk. Selain itu 7 desa lainnya adalah level pratama, yaitu : Desa Dawuhan, Desa Sumberejo, Desa Bakal, desa Nduren, Desa Merden, Desa Karangkobar, dan Desa Sampang. Padahal Kabupaten Banjarnegara memiliki 46 desa yang rawan bencana longsor. Hal ini dapat disimpulkan belum setengah dari jumlah desa di Kabupaten Banjarengara rawan longsor telah menjadi Desa Tangguh Bencana. Melalui desa tangguh bencana ini, diharapkan dapat meminimalisir jumlah korban jiwa dengan mengedepankan upaya mitigas bencana tanah longsor pada saat musim penghujan.

\section{PENUTUP}

Hasil penilaian kapasitas Kabupaten Banjarnegara dalam penyelenggaraan penanggulangan bencana secara keseluruhan dalam 88 indikator mencapai 70,45\%. Hasil persentase ini menjadikan kapasitas daerah Kabupaten Banjarnegara masuk dalam kategori B, yang berarti kapasitas daerah dalam penyelenggaraan penanggulangan bencana baik. Hal yang masih menjadi perhatian utama adalah mengurangi faktor-faktor resiko dasar yang menjadi prioritas ke-4.

Pengurangan faktor-faktor resiko dasar ini dapat dilakukan dengan melakukan berbagai sosialisasi tentang bahaya pemukiman di daerah rawan bencana. Sosialisasi ini menjadi penting karena masih banyak pemukiman yang berada di daerah rawan dengan milihat peta rawan bencana. Perlu adanya kolaborasi dengan Taruna Siaga Bencana (TAGANA) yang telah terbentuk pada masing-masing Desa Tangguh Bencana agar sosialisasi ini dapat berjalan efektif. 


\section{DAFTAR PUSTAKA}

Peraturan Kepala Badan Nasional Penanggulangan Bencana (No 1 Tahun 2012) Tentang: Pedoman Umum Desa, 01 C.F.R. (2012a).

Peraturan Kepala Badan Nasional Penanggulangan Bencana Nomor 03 Tahun 2012 tentang Panduan Penilaian Kapasitas Daerah dalam Penanggulangan Bencana, 03 C.F.R. (2012b).

Undang-Undang Nomor 24 Tahun 2007 tentang Penanggulangan Bencana, 24 C.F.R. (2007).

Peraturan Pemerintah Nomor 21 Tahun 2008 tentang Penyelenggaraan Penanggulangan Bencana 21 C.F.R. (2008).

Iskandar, D. A. (2004). Kajian Standar Kapasitas Institusi Perencanaan Pemerintah Pusat dan Pemerintah Daerah.

Mubekti, M. (2011). Mitigasi Daerah Rawan Tanah Longsor Menggunakan Teknik Pemodelan Sistem Informasi Geografis; Studi Kasus: Kecamatan Sumedang Utara dan Sumedang Selatan. Jurnal Teknologi Lingkungan, 9(2).

Rahman, A. Z. (2015). Kajian Mitigasi Bencana Tanah Longsor di Kabupaten Banjarnegara. GEMA PUBLICA, $1(01)$.

UNDP. (2009). Capacity Needs Assessment In Disaster Risk Reduction : County, District and Community Assessment.

Wuryanti, T. (2006). Kerangka Aksi Hyogo: Pengurangan Resiko Bencana 2005-2015 Membangun Ketahanan Bangsa dan Komunitas Terhadap Bencana. MPBI. Jakarta. 